\title{
Quality of life outcomes in thalassaemia patients in Saudi Arabia: a cross-sectional study
}

\author{
Soheir Adam ${ }^{1,2}$
}

${ }^{1}$ Department of Hematology, King Abdulaziz University, Jeddah, Saudi Arabia (Correspondence to: S. Adam: sadam@kau.edu.sa). ${ }^{2}$ Department of Medicine, Duke University Medical Center, Durham, United States of America.

\begin{abstract}
Background: Research focusing on health-related quality of life (HRQoL) in thalassaemia patients remains limited in Saudi Arabia.

Aims: To report on HRQoL outcomes in thalassaemia patients, and study associations with psychosocial and clinical factors.

Methods: Thalassaemia patients attending King Abdulaziz University Hospital were sequentially approached for enrolment. HRQoL outcomes were assessed using a validated Arabic version of the Medical Outcomes Study Short form (SF-36).

Results: This study included 105 individuals with $\beta$-thalassaemia major, with a mean age of $22.9( \pm 11.7)($ range $5-35)$ years, and $52.4 \%$ were male. Participants aged $\geq 14$ years had a mean physical HRQoL score of $43.7( \pm 10.1)$ and mental HRQoL score of 46.6 ( \pm 10.5$)$. Participants aged $<14$ years, had corresponding scores of $48.4( \pm 10.7)$ and $52.9( \pm 8.0)$, respectively. Physical functioning scores were significantly worse for older patients, and those reporting chronic pain. Lower scores of vitality were associated with older age, chronic pain and history of splenectomy. Older age and history of splenectomy were associated with lower scores of mental health. Controlling for other variables, younger age and higher pretransfusion haemoglobin were associated with better mental HRQoL. Professional workers had better physical HRQoL scores compared to nonprofessional workers..
\end{abstract}

Conclusions: Controlling for other variables, higher pretransfusion haemoglobin and younger age were associated with better mental HRQoL outcomes in thalassaemia patients. Professionals reported better physical HRQoL outcomes, compared to non-professionals. Preventive and comprehensive care models are needed in Saudi Arabia to improve HRQoL outcomes in thalassaemia patients.

Keywords: age, haemoglobin, quality of life, Saudi Arabia, thalassaemia.

Citation: Adam S. Quality of life outcomes in thalassemia patients in Saudi Arabia: a cross-sectional study. East Mediterr Health J. 2019;25(12):887-895 https://doi.org/10.26719/2019.25.12.887

Received: 28/09/17; accepted: 12/03/18

Copyright (C) World Health Organization (WHO) 2019. Some rights reserved. This work is available under the CC BY-NC-SA 3.0 IGO license (https:// creativecommons.org/licenses/by-nc-sa/3.o/igo).

\section{Introduction}

Haemoglobinopathies, including thalassaemia, are considered a serious health care burden worldwide. Although originally more prevalent in the Mediterranean and Sub-Saharan regions, with the high rates of immigration, their prevalence has increased globally $(1-4)$. An estimated 300000 children are born with haemoglobinopathy every year, and $7 \%$ of the world's population are carriers $(1,4,5)$. Countries in the Gulf Region, including Saudi Arabia, have reportedly the highest prevalence rates of haemoglobinopathy worldwide (6). In Saudi Arabia, data derived from the Saudi Premarital Screening Program database, which includes $>480000$ individuals, showed that $3.22 \%$ of the screened population were carriers, and around $0.07 \%$ had thalassaemia (7).

Thalassaemia is an inherited haemolytic anaemia characterized by a decrease or complete absence of globin chain production (1). Thalassaemia has a wide phenotypic spectrum and $\beta$-thalassaemia major is a severe transfusion-dependent form of the disease, associated with numerous complications caused by tissue hypoxygenation and iron overload. The 2 main sources of iron overload are repeated transfusions and increased intestinal iron absorption (8). In high-income countries, provision of safe blood transfusions, oral and parenteral iron chelating agents, noninvasive and regular iron monitoring, plus many other methods of supportive care, are among the numerous measures implemented to prevent disease-related complications and improve outcomes for thalassaemia patients $(9,10)$. However, in countries with limited resources, these measures are difficult to adopt and sustain, especially with other challenges complicating transfusion therapy, such as red cell alloimmunization (11,12), transmission of chronic infections (11-13), iron overload leading to tissue injury and end-organ damage (14,15), and adverse effects associated with chelating agents (15).

As a chronic disorder, thalassaemia is a clinical and psychosocial burden for patients and their families, and despite progress in clinical management, there has been little improvement in health-related quality of life (HRQoL) (16). Measurement of HRQoL for these patients 
is essential to assess the true burden of thalassaemia. HRQoL can clearly define the individual needs of patients, and better inform their disease management plans (17). Despite the high rates of thalassaemia in Saudi Arabia, research on HRQoL remains limited. This study aimed to assess HRQoL of children and adults with thalassaemia in Jeddah, Saudi Arabia, and its association with clinical and psychosocial characteristics.

\section{Methods}

\section{Study design}

This cross-sectional study was conducted at a tertiary care academic hospital: King Abdulaziz University Hospital (KAUH) in Jeddah, Saudi Arabia. The study was approved by KAUH Ethical Committee, and other administrative authorization was obtained before the start of data collection. We approached all patients diagnosed with thalassaemia who attended haematology outpatient clinics at KAUH between March 2015 and July 2016 for enrolment. Patients were only excluded if they were unable or unwilling to participate in the study.

\section{Ethical approval}

All procedures were in accordance with the ethical standards of the institutional and/or national research committee, and with the 1964 Helsinki Declaration and its later amendments or comparable ethical standards. After explaining the study design and objectives, informed consent was obtained from the participants or guardians of children aged $<16$ years. The study size was based on the number of patients who were attending outpatient clinics regularly.

\section{Data collection}

The Medical Outcomes Study Short Form (SF-36) is a 36-item tool for measuring health status and outcomes from the patient's perspective, and the English version is considered a reliable measure for assessing HRQoL subscales (18). The same questionnaire was translated into Arabic, and tested for internal consistency and reliability in a sample from the Saudi Arabian population (19). Data were collected using the SF-36 questionnaire during an interview with a trained data collector. Questionnaires were distributed to patients, and interviewers explained the purpose and content of the questionnaire, and then reassured participants about the confidentiality of their personal data. Adult patients ( $\geq 14$ years) filled in the questionnaires independently, whereas paediatric patients $(<14$ years) filled in the questionnaire jointly with their parents. The questionnaire covered 2 sections. Section A focused on 3 major domains of patient data: demographic data, clinical characteristics and social data. Data about patient demographics included age, sex, educational level, employment status and nature of occupation. For current disease characteristics, participants were asked to report on chronic pain, pain medication and chelation therapy. For the social domain, we collected data on parental education and employment, family history, and number of diseased siblings, if any. In section B, participants were asked to self-assess their HRQoL by rating their own perception and satisfaction about 10 components: physical functioning, physical role, bodily pain, general health, vitality, social functioning, emotional role, mental health, physical component summary and mental component summary. Data were scored based on the system adopted from the RAND study, in which each component was represented as a single variable, scaled from o (poor health) to 100 (good health) (18).

Potential recall bias was addressed by offering patients ample time and complete privacy while filling in the questionnaires. Any missing data were brought to the researcher's attention and addressed individually by contacting participants or by review of electronic medical records.

Medical records were reviewed for clinical history, including: complete blood counts; pre-transfusion haemoglobin; serum ferritin as a marker of iron overload; liver function tests; urea and electrolytes; history of splenectomy; and echocardiographic evidence of pulmonary hypertension (defined as tricuspid regurgitation velocity $\geq 2.5 \mathrm{~m} / \mathrm{s}$ ). Each haematological and biochemical parameter was reported as a mean value over the last 3 months.

\section{Statistical analysis}

The data were analysed using IBM SPSS version 22 (SPSS, Chicago, IL, USA). Simple descriptive statistics were used to define the study variables; counts and percentages for categorical and nominal variables, and means and standard deviations (SDs) for continuous variables. To establish a relationship between patient characteristics and health outcomes, a $\chi^{2}$ test was used for categorical variables, and independent $t$ test for continues variables. $P<$ 0.05 was considered to be statistically significant.

\section{Linear regression analysis}

In order to identify factors associated with physical and mental health and to control for confounders, we constructed 2 multivariate linear regression models. The dependent variable in the first and second models was physical component summary and mental component summary, respectively. We used backwards elimination to select the variables for each regression model. We estimated the regression coefficients $(\beta)$ and their 95\% confidence intervals. For all statistical tests, $P<0.05$ was defined as the level of significance.

\section{Results}

\section{Patient population}

All patients approached consecutively agreed to participate in the study. We enrolled $105 \beta$-thalassaemia major patients [55 male, 50 female, mean (SD) age 22.2 (11.7) years, range 5-35 years] (Table 1). Seventy-six (72.4\%) patients reported at least 1 sibling with thalassaemia. All participants completed questionnaires successfully and there were no missing data at the time of the analysis. 


\begin{tabular}{|c|c|c|c|}
\hline Characteristics & Total $(n=105)$ & Male $(n=55)$ & Female $(n=50)$ \\
\hline & & Mean (SD) & \\
\hline Age (years) & $22.9 \pm 11.7$ & $22.2 \pm 9.7$ & $21.9 \pm 8.8$ \\
\hline \multirow[t]{2}{*}{ Serum ferritin $(\mathrm{ng} / \mathrm{mL})$} & $3257.39 \pm 2113.3$ & $3194.67 \pm 2119$ & $3326.38 \pm 2169$ \\
\hline & & $\mathbf{N}(\%)$ & \\
\hline \multicolumn{4}{|l|}{ Education level $(n=105)$} \\
\hline Illiterate & $12(11.4 \%)$ & $7(58.3 \%)$ & $5(41.7 \%)$ \\
\hline School & $81(77.2 \%)$ & $41(50.6 \%)$ & $40(49.4 \%)$ \\
\hline College graduate & $12(11.4 \%)$ & $7(58.3 \%)$ & $5(41.7 \%)$ \\
\hline \multicolumn{4}{|c|}{ Employment status (n = 105) } \\
\hline Unemployed & $87(82.9 \%)$ & $42(47.7 \%)$ & $46(52.3 \%)$ \\
\hline Employed & $18(17.1 \%)$ & $13(76.5 \%)$ & $4(23.5 \%)$ \\
\hline \multicolumn{4}{|c|}{ Diseased siblings $(n=105)$} \\
\hline Yes & $76(72.4 \%)$ & $41(53.9 \%)$ & $35(46.1 \%)$ \\
\hline No & $29(27.6 \%)$ & $14(48.3 \%)$ & $15(51.7 \%)$ \\
\hline \multicolumn{4}{|l|}{ Chronic pain $(n=105)$} \\
\hline Yes & $94(89.5 \%)$ & $53(56.4 \%)$ & $41(43.6 \%)$ \\
\hline No & $11(10.5 \%)$ & $2(18.2 \%)$ & $9(81.8 \%)$ \\
\hline \multicolumn{4}{|l|}{ Chelation ( $n=105$ ) } \\
\hline Yes & $2(1.9 \%)$ & $2(100 \%)$ & $\mathrm{o}(0 \%)$ \\
\hline No & $103(98.1 \%)$ & $53(51.5 \%)$ & $50(48.5 \%)$ \\
\hline \multicolumn{4}{|l|}{ Splenectomy $(n=105)$} \\
\hline Yes & $64(60.9 \%)$ & $33(51.6 \%)$ & $31(48.4 \%)$ \\
\hline No & $41(39.1 \%)$ & $22(53.7 \%)$ & $19(46.3 \%)$ \\
\hline \multicolumn{4}{|c|}{ Pretransfusion haemoglobin $(n=105)$} \\
\hline$\geq 8.7 \mathrm{~g} / \mathrm{dL}$ & $28(26.7 \%)$ & $10(35.7 \%)$ & $18(64.3 \%)$ \\
\hline$\leq 8.6 \mathrm{~g} / \mathrm{dL}$ & $77(73.3 \%)$ & $45(58.4 \%)$ & $32(41.6 \%)$ \\
\hline \multicolumn{4}{|c|}{ Tricuspid regurgitation $(n=76)$} \\
\hline$\geq 2.5 \mathrm{~m} / \mathrm{s}$ & $3(3.9 \%)$ & $2(66.7 \%)$ & $1(33.3 \%)$ \\
\hline$<2.5 \mathrm{~m} / \mathrm{s}$ & $73(96.1 \%)$ & $38(52.1 \%)$ & $35(47.9 \%)$ \\
\hline
\end{tabular}

$S D=$ standard deviation

\section{Education and employment}

Only $12(11.4 \%)$ patients were college graduates, and most $(81,77.2 \%)$ either only finished school or were still students (Table 1). Eighty-seven (82.9\%) patients were unemployed. Among the 18 (17.1\%) who were employed, 11 were professionals and 7 were working in various manual and clerical jobs. For paediatric patients, $6(27.6 \%)$ of their fathers were college graduates, 11 (49.5\%) of them finished high school, and 5 (22.9\%) were illiterate. Only $3(12.4 \%)$ of their mothers were college graduates, while more than half $(12 ; 52.4 \%)$ finished high school, and 3 (35.2\%) were illiterate.

\section{Disease complications}

Ninety-four (89.5\%) patients complained of chronic pain, $64(60.9 \%)$ underwent splenectomy, and only 2 (1.9\%) were taking chelating agents (Table 1). For 77 (73.3\%) patients, mean pretransfusion haemoglobin levels were $\leq$ $8.6 \mathrm{~g} / \mathrm{dL}$ and mean ferritin level for all patients was 3257.4
(2113.3) ng/mL. Seventy-six patients (72\%), had recent records of echocardiographic screening, but only 3 (3.9\%) showed evidence of pulmonary hypertension (tricuspid regurgitation velocity $\geq 2.5 \mathrm{~m} / \mathrm{s}$ ). Further details of all patients' characteristics, and differences between males and females are shown in Table 1.

\section{Physical HRQoL outcomes}

Patients aged > 14 years reported significantly lower scores for physical functioning $(P=0.015)$, vitality $(P<$ 0.001 ) (Table 2) and overall physical component summary $(P=0.047)$, compared to the younger age group (Figure $1 \mathrm{~A})$. Patients, aged $\leq 14$ years showed more evidence of role limitations due to physical health $(P=0.002)$, and significantly higher scores for bodily pain $(P=0.040)$ (Table 2). Patients experiencing chronic pain reported lower scores for physical functioning $(P=0.004)$, general health $(P=0.004)$, vitality $(P=0.012)$ and physical component summary $(P<0.001)$. Being in school and age $>14$ years were significantly associated with lower scores for physi- 


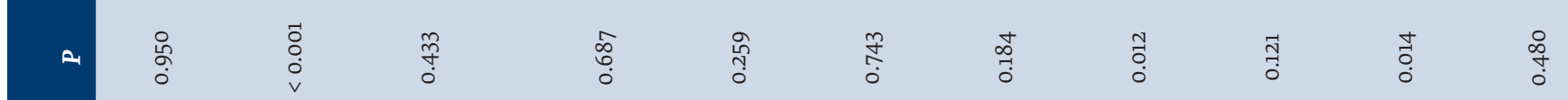

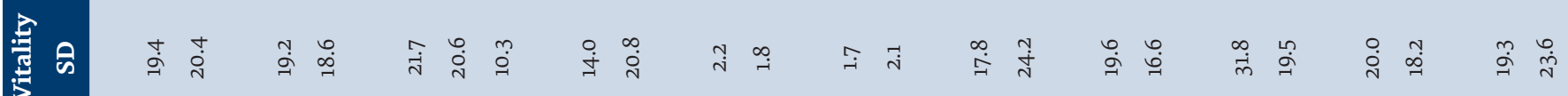

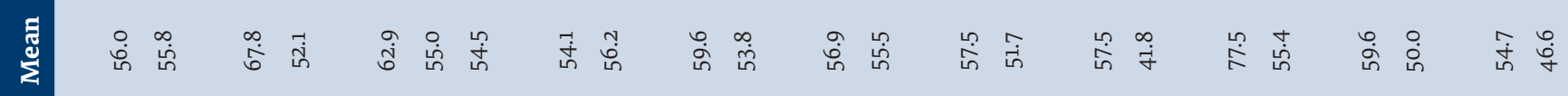

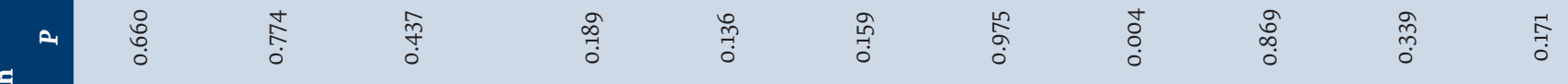

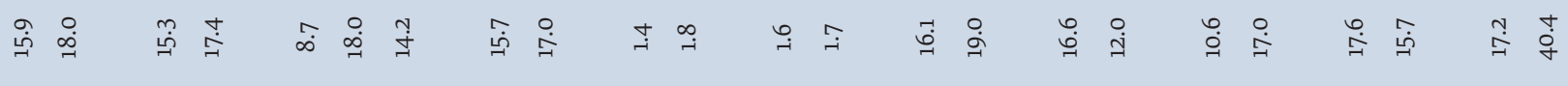

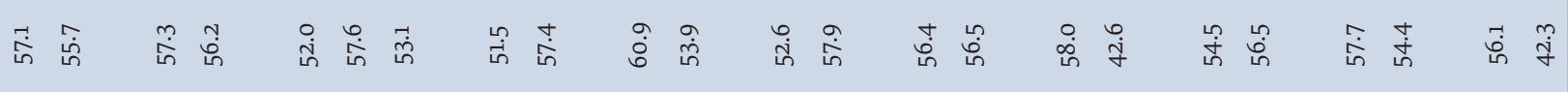

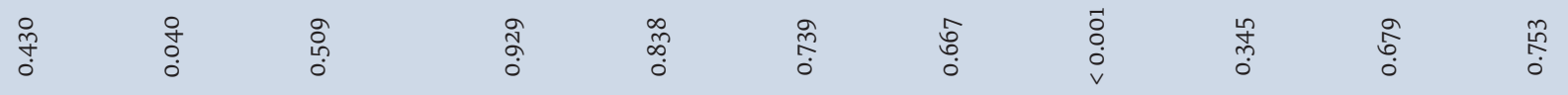
晨

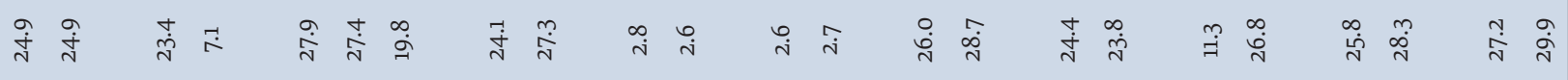

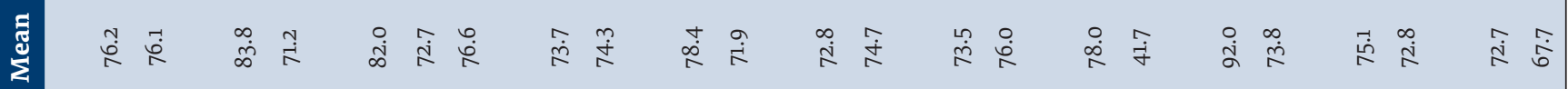

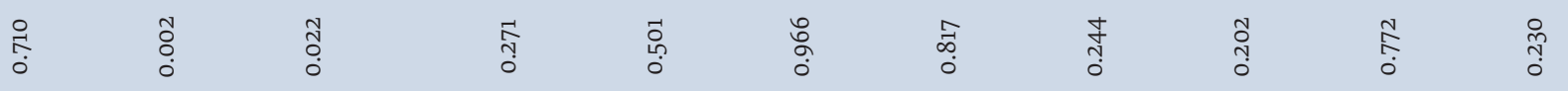

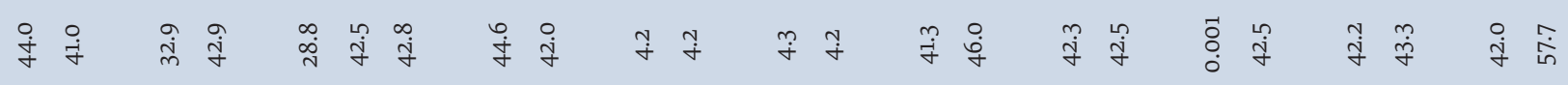

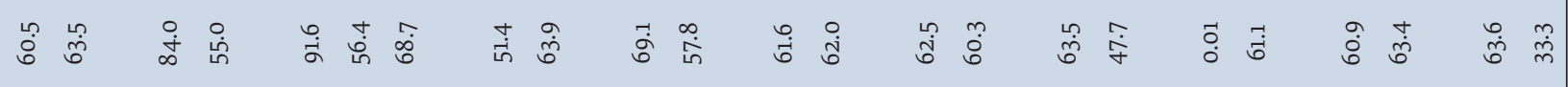

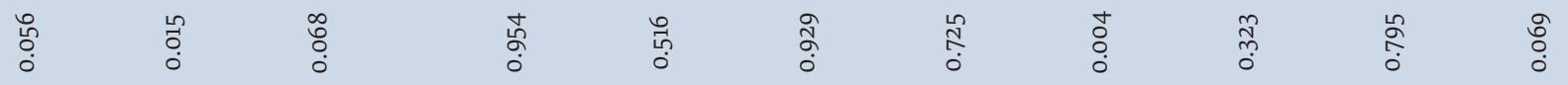

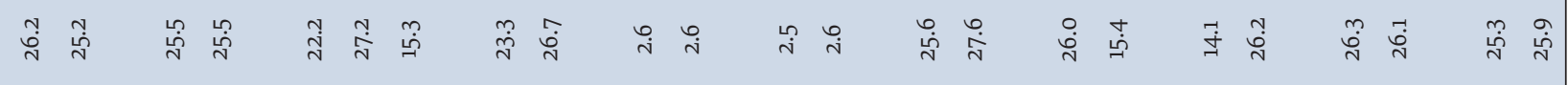

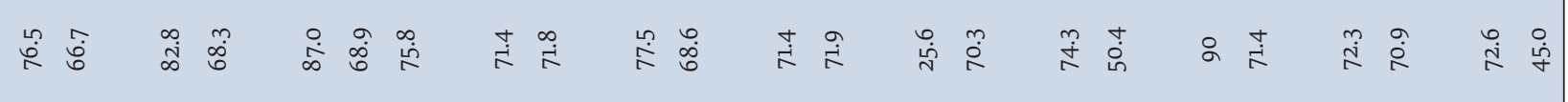




\begin{tabular}{|c|c|c|c|c|c|c|c|c|c|c|c|c|c|c|c|}
\hline \multirow[t]{2}{*}{ Characteristics } & \multicolumn{3}{|c|}{$\begin{array}{c}\text { Social } \\
\text { functioning }\end{array}$} & \multicolumn{3}{|c|}{$\begin{array}{c}\text { Role } \\
\text { emotional }\end{array}$} & \multicolumn{3}{|c|}{$\begin{array}{l}\text { Mental } \\
\text { health }\end{array}$} & \multicolumn{3}{|c|}{$\begin{array}{l}\text { Physical } \\
\text { summary }\end{array}$} & \multicolumn{3}{|c|}{$\begin{array}{l}\text { Mental } \\
\text { summary }\end{array}$} \\
\hline & Mean & SD & $\mathbf{P}$ & Mean & SD & $\mathbf{P}$ & Mean & SD & $\mathbf{P}$ & Mean & SD & $\mathbf{P}$ & Mean & SD & $\mathbf{P}$ \\
\hline \multicolumn{16}{|l|}{ Sex } \\
\hline Male & 80.9 & 23.5 & 0.970 & 69.0 & 39.9 & 0.290 & 67.1 & 18.7 & 0.900 & 46.1 & 10.7 & 0.170 & 47.0 & 10.3 & 0.280 \\
\hline Female & 80.7 & 25.1 & & 77.3 & 39.5 & & 67.6 & 19.8 & & 43.4 & 9.9 & & 49.2 & 10.5 & \\
\hline \multicolumn{16}{|l|}{ Age, years } \\
\hline$\leq 14$ & 87.0 & 20.5 & 0.145 & 93.3 & 33.3 & 0.003 & 76.1 & 12.9 & 0.008 & 48.4 & 10.7 & 0.047 & 52.9 & 8.0 & 0.008 \\
\hline$>14$ & 78.9 & 25.0 & & 66.6 & 39.6 & & 64.6 & 20.0 & & 43.7 & 10.1 & & 46.6 & 10.5 & \\
\hline \multicolumn{16}{|l|}{ Patient education } \\
\hline Illiterate & 91.6 & 18.7 & 0.194 & 80.5 & 38.8 & 0.765 & 62.6 & 16.3 & 0.503 & 51.4 & 8.9 & 0.038 & 47.0 & 10.0 & 0.733 \\
\hline School level & 78.7 & 25.0 & & 72.4 & 41.0 & & 68.5 & 20.1 & & 43.5 & 10.5 & & 48.5 & 10.8 & \\
\hline $\begin{array}{l}\text { College } \\
\text { graduate }\end{array}$ & 84.3 & 21.4 & & 69.4 & 33.2 & & 64.0 & 14.7 & & 46.8 & 9.0 & & 46.3 & 8.3 & \\
\hline \multicolumn{16}{|l|}{ Employment status } \\
\hline Unemployed & 80.8 & 21.7 & 0.993 & 68.6 & 38.1 & 0.662 & 71.7 & 18.3 & 0.303 & 42.7 & 9.6 & 0.358 & 49.0 & 9.9 & 0.703 \\
\hline Employed & 80.8 & 24.7 & & 73.8 & 40.2 & & 66.5 & 19.3 & & 45.2 & 10.5 & & 47.9 & 10.6 & \\
\hline \multicolumn{16}{|c|}{ Ferritin level, $\mathrm{ng} / \mathrm{mL}$} \\
\hline$<2000$ & 86.5 & 2.4 & 0.464 & 79.8 & 4.2 & 0.740 & 71.5 & 17.2 & 0.391 & 46.9 & 11.5 & 0.229 & 50.2 & 10.7 & 0.664 \\
\hline$\geq 2000$ & 77.6 & 2.4 & & 69.2 & 3.8 & & 65.0 & 19.9 & & 43.7 & 9.7 & & 46.9 & 10.2 & \\
\hline \multicolumn{16}{|c|}{ Pretransfusion haemoglobin, g/dL } \\
\hline$<8$ & 74.6 & 2.5 & 0.109 & 66.7 & 4.2 & 0.327 & 62.3 & 18.1 & 0.103 & 45.1 & 9.5 & 0.883 & 45.4 & 10.4 & 0.112 \\
\hline$\geq 8$ & 83.1 & 2.4 & & 75.3 & 3.9 & & 69.2 & 19.3 & & 44.8 & 10.8 & & 49.1 & 10.4 & \\
\hline \multicolumn{16}{|l|}{ Diseased siblings } \\
\hline 1 or 2 & 81.0 & 22.6 & 0.864 & 73.2 & 40.0 & 0.924 & 67.0 & 19.1 & 0.762 & 44.9 & 10.2 & 0.852 & 48.2 & 10.2 & 0.879 \\
\hline$\geq 3$ & 80.1 & 28.2 & & 72.4 & 39.9 & & 68.2 & 19.6 & & 44.5 & 11.1 & & 47.8 & 11.1 & \\
\hline \multicolumn{16}{|l|}{ Chronic pain } \\
\hline No & 83.6 & 22.7 & $<0.001$ & 73.0 & $37 \cdot 3$ & 0.980 & 68.5 & 18.5 & 0.070 & 46.0 & 9.9 & $<0.001$ & 48.4 & 10.0 & 0.306 \\
\hline Yes & 56.8 & 23.9 & & 72.7 & 59.2 & & 57.4 & 22.6 & & 34.4 & 8.5 & & 45.0 & 13.7 & \\
\hline \multicolumn{16}{|l|}{ Chelation therapy } \\
\hline Receiving & 100 & 00.0 & 0.260 & 100 & 00.0 & 0.335 & 74.0 & 31.1 & 0.623 & 52.1 & 0.9 & 0.319 & 54.2 & 10.9 & 0.405 \\
\hline Not receiving & 80.4 & 24.2 & & 72.4 & 39.9 & & 67.2 & 19.1 & & 44.7 & 10.4 & & 48.0 & 10.4 & \\
\hline \multicolumn{16}{|l|}{ Splenectomy } \\
\hline No & 81.8 & 23.6 & 0.598 & 74.4 & 39.7 & 0.640 & 71.4 & 17.2 & 0.006 & 44.5 & 10.0 & 0.748 & 49.9 & 9.6 & 0.029 \\
\hline Yes & 79.2 & 25.2 & & 70.7 & 40.2 & & 60.9 & 20.4 & & 45.2 & 11.1 & & 45.3 & 11.1 & \\
\hline \multicolumn{16}{|c|}{ Pulmonary hypertension } \\
\hline No & 79.6 & 25.0 & 0.386 & 73.0 & 36.2 & 0.073 & 67.8 & 18.7 & 0.190 & 44.8 & 9.9 & 0.259 & 47.9 & 10.0 & 0.213 \\
\hline Yes & 66.6 & 31.4 & & 33.3 & 57.7 & & 53.3 & 11.5 & & 38.2 & 10.4 & & 40.5 & 10.2 & \\
\hline
\end{tabular}

Bold figures are significant values. $S D=$ standard deviation.

cal component summary $(P=0.038$ and 0.047 , respectively). Among different educational levels, illiterate patients experienced more role limitations due to physical health $(P=0.022)$. A history of splenectomy was significantly associated with lower scores for vitality $(P=0.014)$.

\section{Mental HRQoL outcomes}

Only chronic pain had a significant effect on social functioning $(P<0.001)$, as patients with chronic pain achieved lower scores (Table 3 ). The scores representing role lim- itations due to disturbed emotional wellbeing were significantly higher for patients aged $\leq 14$ years $(P=0.003)$. Patients aged $>14$ years and those with a history of splenectomy reported significantly lower scores for the mental component summary subscale (Figure $1 B)(P=0.008$ and 0.029 , respectively).

\section{Regression analysis}

According to multiple linear regression, professionals had significantly better physical health than patients 


\begin{tabular}{|c|c|c|c|}
\hline Variable & Regression coefficient & 95\% CI & $\mathbf{P}$ \\
\hline \multicolumn{4}{|c|}{ Factors associated with physical component summary outcome score } \\
\hline \multicolumn{4}{|c|}{ Age, years } \\
\hline$\leq 14$ & 1 & & 0.064 \\
\hline$>14$ & -0.18 & -9.17 to 0.27 & \\
\hline \multicolumn{4}{|l|}{ Sex } \\
\hline Male & 1 & & 0.09 \\
\hline Female & -0.17 & -7.44 to 0.55 & \\
\hline \multicolumn{4}{|l|}{ Employment status } \\
\hline Unemployed & 1 & & 0.054 \\
\hline Employed & -0.24 & -13.70 to 0.13 & \\
\hline \multicolumn{4}{|l|}{ Occupational status } \\
\hline Manual or clerical job & 1 & & 0.03 \\
\hline Professional & 0.26 & $1.10-20.79$ & \\
\hline \multicolumn{4}{|c|}{ Factors associated with mental component summary outcome score } \\
\hline \multicolumn{4}{|c|}{ Age, years } \\
\hline$\leq 14$ & 1 & & 0.004 \\
\hline$>14$ & -0.21 & -11.45 to -2.29 & \\
\hline \multicolumn{4}{|c|}{ Pretransfusion haemoglobin, $g / d L$} \\
\hline$\leq 8.6$ & 1 & & 0.048 \\
\hline$\geq 8.7$ & 0.19 & $0.04-8.87$ & \\
\hline
\end{tabular}

Bold values are significant. $C I=$ confidence interval; $H R Q O L=$ health-related quality of life.

with manual or clerical jobs (Table 4). Adults, female patients and employed patients showed a tendency to have worse physical health. Adults had significantly worse mental health than children had, and patients with higher pretransfusion haemoglobin level had significantly better mental health.

\section{Discussion}

The rising rates of thalassaemia globally (20) have encouraged more research to assess disease burden and HRQoL outcomes in this population (21). The present study focused on HRQoL outcomes in thalassaemia patients followed in a tertiary care centre in Jeddah, Saudi Arabia, using the SF-36 questionnaire.

Thalassaemia patients reported low scores on all HRQoL subscales, in agreement with previous reports in other patients with thalassaemia (21-23). We found that age was significantly associated with HRQoL. Patients aged $\leq 14$ years experienced more physical and emotional limitations, complained more of bodily pain, had lower vitality scores, and exhibited worse mental health features than those aged > 14 years. However, older patients had significantly lower scores for both the overall physical and mental summary components, which may have been due to the cumulative effects of long-standing diseaserelated complications. Children demonstrated worse HRQoL features than adults did in a global context (9). Only a few studies have reported on the effect of age on HRQoL. One study among Jordanian children with thalassaemia reported lower physical and emotional scores for those aged 8-12 years when compared to those aged 13-18 years; however, no significant difference was detected between the age groups (22). One explanation to this could be the difference in composition of the study population. In our study we investigated HRQoL outcomes in children and adults with thalassaemia, whereas previous studies in Saudi Arabia or elsewhere in the Middle East either only included paediatric patients (21-25) or adults (26) with thalassaemia.

One clinical factor that was strongly associated with lower HRQoL outcomes, in almost all subscales in our study population, was the presence of chronic pain, which limited daily activity and affected social functioning. These findings agree with 2 other studies in the Middle East: one in Jordan where children complained of limiting pains and low energy when performing their daily activities (22), and another in the Syrian Arab Republic, which reported a significant association with lower physical health scores among children and adolescents with thalassaemia (27). Chronic pain in our study population was associated with lower social functioning, which echoes the findings of the Jordanian study, in which children felt physical inadequacy limited their interactions with their peers (22). While some of these studies were conducted using different HRQoL assessment instruments other than SF-36, all assessment instruments were previously validated in the corresponding population, which renders comparison of results across studies viable.

Although splenectomy is an effective measure to reduce transfusion requirements in thalassaemia, it does not prevent disfiguring skeletal changes, delayed growth and puberty, or chronic pain $(28,29)$. Moreover, splenectomy increases the risk of infection and venous thromboembolism $(28,29)$. In our study, patients who underwent splenectomy had significantly worse mental health and mental health component summary scores, which were most likely caused by the adverse effects of the operation.

Upon controlling for other variables, the association 
between older age and worse mental HRQoL outcomes persisted. Higher levels of pretransfusion haemoglobin positively affected mental HRQoL, and participants holding professional jobs had better mental HRQoL scores compared to those working in clerical or manual jobs.

Several studies on HRQoL reported low psychological and mental health scores for thalassaemia patients, and identified different forms of mental health disorders such as depression, anxiety and stress (30-32). A study from Turkey found that thalassaemia patients and their caregivers suffered from depression and anxiety (32), which represented an additional burden for the families. Few studies have focused on the relationship between mental HRQoL outcomes and patients' socioeconomic and clinical characteristics, despite the importance of psychological and mental integrity to improve disease outcomes (30). The psychological burden is often over looked in Middle Eastern populations, and there is a need to devote more resources to understand this important aspect of the disease.

Comprehensive management models should ideally be developed to cater for individual patient needs, empower patients and support family members. Raising awareness and education in the community will facilitate social integration of thalassaemia patients and ultimately improve HRQoL outcomes.

The following limitations to our study should be acknowledged. The study focused only on patients and did not include HRQoL of their caregivers; a factor that significantly increased the disease burden. There was concern for potential bias, including patients' report of pain and other symptoms. Patients were given complete privacy and an adequate time to fill in the forms in order to avoid recall bias. There was also concern for selection bias as we only included thalassaemia patients from a single centre, and most of the participants attended clinics regularly and were thus considered to be more compliant and vigilant about their health management. However, since KAUH has the largest number of thalassaemia patients in Saudi Arabia and all participants were approached consecutively at the time of their outpatient visits, we believe that they were representative of the thalassaemia population.

In conclusion, thalassaemia is a chronic disease with myriad complications, presenting serious challenges to patients and families. There is a need for comprehensive care centres in Saudi Arabia to improve HRQoL outcomes in thalassaemia through providing early preventive care, as well as social and psychological support to patient and families.

\section{Acknowledgements}

The author would like to thank Drs. Hind Hussein, Anoud Omar and Abdulmoneim Mokhtar for their valuable input and statistical insight. The author is grateful for the support and contribution of patients and their families.

Funding: None.

Competing interests: None declared.

\section{Résultats en matière de qualité de vie des patients thalassémiques en Arabie saoudite : étude transversale \\ Résumé}

Contexte : Les recherches sur la qualité de vie liée à la santé (QVLS) des patients thalassémiques restent limitées en Arabie saoudite.

Objectifs : La présente étude visait à présenter les résultats du questionnaire sur la QVLS des patients thalassémiques ainsi qu'à étudier les associations avec les facteurs psychosociaux et cliniques.

Méthodes : Les patients thalassémiques qui consultaient à l'Hôpital universitaire Roi Abdulaziz ont été contactés lors de leur visite pour participer à l'étude. Les résultats du questionnaire sur la QVLS ont été évalués à l'aide d'une version arabe validée de la forme abrégée du questionnaire généraliste SF-36 du Medical Outcomes Study.

Résultats : L'étude a été menée auprès de 105 personnes atteintes de bêta-thalassémie majeure, dont l'âge moyen était de 22,9 ans ( $\pm 11,7)$ (âge compris entre 5 à 35 ans), et 52,4 \% étaient des hommes. Les participants adultes âgés de 14 ans et plus ont obtenu un score moyen de 43,7 ( $\pm 10,1)$ dans la sous-échelle physique du questionnaire sur la QVLS et un score de 46,6 ( $\pm 10,5)$ dans la sous-échelle mentale du questionnaire. Les participants de moins de 14 ans ont obtenu des scores correspondants de 48,4 $( \pm 10,7)$ et $52,9( \pm 8,0)$ respectivement. Les scores pour le fonctionnement physique étaient significativement moindres chez les patients plus âgés ainsi que pour ceux qui signalaient une douleur chronique. Des scores plus faibles pour la sous-échelle vitalité étaient associés à un âge plus avancé, à la douleur chronique et aux antécédents de splénectomie. Un âge plus avancé et des antécédents de splénectomie étaient associés à des scores plus faibles pour la santé mentale. En tenant compte d'autres variables, un âge plus jeune et une hémoglobine pré-transfusionnelle plus élevée étaient associés à un meilleur score pour la sous-échelle mentale du questionnaire sur la QVLS. Les cadres ont obtenu de meilleurs scores pour la sous-échelle physique du questionnaire que les non-cadres. 
Conclusion : En tenant compte d'autres variables, un taux d'hémoglobine pré-transfusionnelle plus élevé et un plus jeune âge étaient associés à de meilleurs scores pour la sous-échelle mentale du questionnaire sur la QVLS des patients thalassémiques. Les cadres faisaient état de meilleurs résultats physiques dans le questionnaire par rapport aux non-cadres. Des modèles de soins préventifs et complets sont nécessaires en Arabie saoudite pour améliorer les scores du questionnaire sur la QVLS des patients thalassémiques.

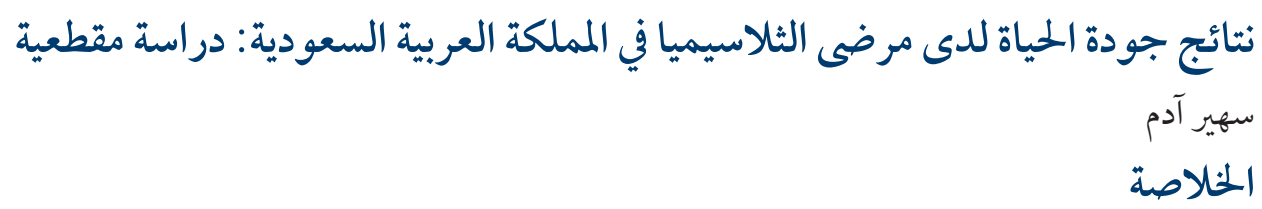

\section{References}

1. Modell B, Darlison M. Global epidemiology of haemoglobin disorders and derived service indicators. Bull World Health Organ. 2008 Jun;86(6):480-7. PMID:18568278

2. Livingstone FB. Frequencies of hemoglobin variants : thalassemia, the glucose-6-phosphate dehydrogenase deficiency, G6PD variants, and ovalocytosis in human populations. New York: Oxford University Press; 1985.

3. Weatherall DJ. Phenotype-genotype relationships in monogenic disease: lessons from the thalassaemias. Nat Rev Genet. 2001 Apr;2(4):245-55. PMID:11283697

4. Weatherall DJ. The inherited diseases of hemoglobin are an emerging global health burden. Blood. 2010 Jun 3;115(22):4331-6. http://dx.doi.org/10.1182/blood-2010-01-251348 PMID:20233970

5. Weatherall DJ, Clegg JB. Inherited haemoglobin disorders: an increasing global health problem. Bull World Health Organ. 2001;79(8):704-12. PMID:11545326

6. Hamamy HA, Al-Allawi NA. Epidemiological profile of common haemoglobinopathies in Arab countries. J Community Genet. 2013 Apr;4(2):147-67. Http://dx.doi.org/10.1007/s12687-012-0127-8 PMID:23224852

7. Alhamdan NA, Almazrou YY, Alswaidi FM, Choudhry AJ. Premarital screening for thalassemia and sickle cell disease in Saudi Arabia. Genet Med. 2007 Jun;9(6):372-7. http://dx.doi.org/10.1097GIM.obo13e318065a9e8 PMID:17575503

8. Taher AT, Weatherall DJ, Cappellini MD. Thalassaemia. Lancet. 2018 Jan 13;391(10116):155-67. http://dx.doi.org/10.1016/So1406736(17)31822-6 PMID:28774421

9. Amid A, Saliba AN, Taher AT, Klaassen RJ. Thalassaemia in children: from quality of care to quality of life. Arch Dis Child. 2015 Nov;100(11):1051-7. http://dx.doi.org/10.1136/archdischild-2014-308112 PMID26289062

10. Rund D. Thalassemia 2016: Modern medicine battles an ancient disease. Am J Hematol. 2016 Jan;91(1):15-21. http://dx.doi. org/10.1002/ajh.24231 PMID:26537527

11. Vichinsky E, Neumayr L, Trimble S, Giardina PJ, Cohen AR, Coates T, et al. Transfusion complications in thalassemia patients: a report from the Centers for Disease Control and Prevention (CME). Transfusion. 2014 Apr;54(4):972-81. http://dx.doi.org/10.1111/ trf.12348 PMID:23889533 
12. Goss C, Giardina P, Degtyaryova D, Kleinert D, Sheth S, Cushing M. Red blood cell transfusions for thalassemia: results of a survey assessing current practice and proposal of evidence-based guidelines. Transfusion. 2014 Jul;54(7):1773-81. http://dx.doi. org/10.1111/trf.12571 PMID:24611697

13. Borgna-Pignatti C, Garani MC, Forni GL, Cappellini MD, Cassinerio E, Fidone C, et al. Hepatocellular carcinoma in thalassaemia: an update of the Italian Registry. Br J Haematol. 2014 Oct;167(1):121-6. http://dx.doi.org/10.1111/bjh.13009 PMID:24992281

14. Wood JC. Estimating tissue iron burden: current status and future prospects. Br J Haematol. 2015 Jul;170(1):15-28. http://dx.doi. org/10.1111/bjh.13374 PMID:25765344

15. Piga A, Longo F, Musallam KM, Cappellini MD, Forni GL, Quarta G, et al. Assessment and management of iron overload in $\beta$-thalassaemia major patients during the 21st century: a real-life experience from the Italian WEBTHAL project. Br J Haematol. 2013 Jun;161(6):872-83. http://dx.doi.org/10.1111/bjh.12340 PMID:23600689

16. Musallam K, Cappellini MD, Taher A. Challenges associated with prolonged survival of patients with thalassemia: transitioning from childhood to adulthood. Pediatrics. 2008 May;121(5):e1426-9.

17. Panepinto JA. Health-related quality of life in patients with hemoglobinopathies. Hematology Am Soc Hematol Educ Program. 2012;2012:284-9. http://dx.doi.org/10.1182/asheducation-2012.1.284 PMID:23233593

18. Ware JE Jr, Sherbourne CD. The MOS 36-item short-form health survey (SF-36). I. Conceptual framework and item selection. Med Care. 1992 Jun;30(6):473-83. PMID:1593914

19. Coons SJ, Alabdulmohsin SA, Draugalis JR, Hays RD. Reliability of an Arabic version of the RAND-36 Health Survey and its equivalence to the US-English version. Med Care. 1998 Mar;36(3):428-32. PMID:9520966

20. Mikelli A, Tsiantis J. Brief report: depressive symptoms and quality of life in adolescents with b-thalassaemia. J Adolesc. 2004 Apr;27(2):213-6. http://dx.doi.org/10.1016/j.adolescence.2003.11.011 PMID:15023520

21. Mevada ST, Al Saadoon M, Zachariah M, Al Rawas AH, Wali Y. Impact of burden of thalassemia major on health-related quality of life in Omani children. J Pediatr Hematol Oncol. 2016 Jul;38(5):384-8. http://dx.doi.org/10.1097/MPH.0000000000000565 PMID:27164523

22. Gharaibeh HF, Gharaibeh MK. Factors influencing health-related quality of life of thalassaemic Jordanian children. Child Care Health Dev. 2012 Mar;38(2):211-8. http://dx.doi.org/10.1111/j.1365-2214.2011.01224.x PMID:21426370

23. Caocci G, Efficace F, Ciotti F, Roncarolo MG, Vacca A, Piras E, et al. Health related quality of life in Middle Eastern children with beta-thalassemia. BMC Blood Disord. 2012 Jun 22;12:6. http://dx.doi.org/10.1186/1471-2326-12-6 PMID:22726530

24. Ayoub MD, Radi SA, Azab AM, Abulaban AA, Balkhoyor AH, Bedair SW, et al. Quality of life among children with beta-thalassemia major treated in Western Saudi Arabia. Saudi Med J. 2013 Dec;34(12):1281-6. PMID:24343469

25. Adam S, Afifi H, Thomas M, Magdy P, El-Kamah G. Quality of life outcomes in a pediatric thalassemia population in Egypt. Hemoglobin. 2017 Jan;41(1):16-20. http://dx.doi.org/10.1080/03630269.2017.1312434 PMID:28440111

26. Amoudi AS, Balkhoyor AH, Abulaban AA, Azab AM, Radi SA, Ayoub MD, et al. Quality of life among adults with beta-thalassemia major in western Saudi Arabia. Saudi Med J. 2014 Aug;35(8):882-5. PMID:25129193

27. Gharaibeh H, Amarneh BH, Zamzam SZ. The psychological burden of patients with beta thalassemia major in Syria. Pediatr Int. 2009 Oct;51(5):630-6. http://dx.doi.org/10.1111/j.1442-200X.2009.02833.x PMID:19419527

28. Mandal PK, Ghosh MK, Bhattacharyya M. Does profile of hemoglobin ebeta-thalassemia patients change after splenectomy? Experience of a tertiary thalassemia care centre in Eastern India. Indian J Hematol Blood Transfus. 2015 Dec;31(4):446-52. http:// dx.doi.org/10.1007/s12288-014-0498-6 PMID:26306069

29. Cappellini MD, Grespi E, Cassinerio E, Bignamini D, Fiorelli G. Coagulation and splenectomy: an overview. Ann N Y Acad Sci. 2005;1054:317-24. http://dx.doi.org/10.1196/annals.1345.039 PMID:16339680

30. Adib-Hajbaghery M, Ahmadi M, S P. Health related quality of life, depression, anxiety and stress in patients with beta-thalassemia major. Iran J Ped Hematol Oncol. 2015;5(4):193-205. PMID:26985352

31. Marvasti VE, Dastoori P, Karimi M. Is beta-thalassemia trait a risk factor for developing depression in young adults? Ann Hematol. 2006 Dec;85(12):873-4. http://dx.doi.org/10.1007/s00277-006-0154-9 PMID:16845515

32. Yengil E, Acipayam C, Kokacya MH, Kurhan F, Oktay G, Ozer C. Anxiety, depression and quality of life in patients with beta thalassemia major and their caregivers. Int J Clin Exp Med. 2014 Aug 15;7(8):2165-72. PMID:25232402 